\title{
Approaching Laestadianism as an insider researcher
}

\begin{abstract}
$\mathrm{n}$ this article, I discuss my experiences of being an insider researching Laestadianism. I present my research, noting the advantages and disadvantages, ending with a conclusion in which I refer to the discussion among anthropologists and ethnologists, especially in the study of religion. The outcome is that even though the distinction insider-outsider researcher is complicated, both insider and outsider researchers will improve the research, contributing to its nuanced presentation.
\end{abstract}

\section{Introduction}

Upon starting my church-historical research on Laestadian ${ }^{1}$ women (Snellman 2011), I labelled myself as researcher who was female, Laestadian and affiliated to the Laestadian branch located in the northern, Swedish-speaking area of Ostrobothnia in Finland. Though acknowledging the challenge of being part of my studied object, I was unaware at that time of the ongoing insider-outsider debate (see McCutcheon 1999). The label 'insider researcher' appeared later in my academic studies.

1 When using the expression 'Laestadian' in different connections, I refer to the Word of Peace branch (WoP), which means, if not separately mentioned, that all other Laestadian branches are excluded in this article. A more detailed description of $\mathrm{WoP}$ is included in the following section.
Yet I knew the study would be challenging because I would be implicated in the study at least on two specific levels - being a woman myself, and further, being a Laestadian woman. The topic was also close to me from another point of view. I was going to do research into the everyday life of a community of women amongst whom I had been surrounded since I was born. There was my mother, my grandmother, and later on, my mother-in-law. Besides, there were an uncountable number of other Laestadian women, mothers, and friends, in the Laestadian community, of which I was a part.

I am an insider researcher, who, according to the standard definition, has been raised in, or converted to, the studied religious group, thus accepting its belief system and values. Outsiders have not had this experience (Duffy 2014: 1-2). The ongoing discussion about the advantages and disadvantages of being either an insider or an outsider researcher has chiefly been carried out in the field of the study of religion. In the anthology, The Insider/Outsider Problem in the Study of Religion (McCutcheon 1999), the theoretical and methodological issues in studying religion are discussed thoroughly. According to Alasdair MacIntyre (1999: 37-49), outsider scholars (skeptics), 
though able to observe religious (Christian) behaviour, are lacking access to the inner meaning of it. In this sense, knowledge includes 'emphatic insights'. Although the relationship between studies in theology and the study of religion seems to be somewhat blurred, scholars in the study of religion have argued against the idea that knowledge about religion epistemologically requires understanding because, according to them, faith in practice - the tradition - theoretically can be analysed by both believers and skeptics (Wiebe 1999: 270; Hedges and King 2014: 43-6). The two standpoints assume that there are boundaries and locations within the position of insider-outsider. The question has, meanwhile, been whether neutrality is desirable - which scholar is better equipped to achieve objectivity (Gregg and Chryssides 2019a: preface).

However, insiders, as well as outsiders, will situate themselves in relation to the studied religion. As an alternative to the two standpoints - either that one needs to be an insider (believer) to study religion (theology) (see Duffy 2014), or that access to a particular form of knowledge does not require insiderness (Gardiner and Engler 2012), many scholars have stressed the shifting identities of both insider and outsider researchers (Narayan 1993; Chavez 2008; Knott 2008; Meintel and Mossière 2012; Iancu and Kovacs 2015). Recently a more nuanced understanding of 'insiderness' and 'outsiderness' has, referring to the complexity of life, been presented. Hence, it is suggested that the use of queer theory methodologies, beyond the binary approach of the past, would benefit understandings of religious identity (Gregg and Chryssides 2019b: 25). Another way of solving the dilemma lies in focusing on how, rather than by whom (insider or outsider), the object of knowledge is constructed; this is called the emic/etic approach (Sutcliffe 2019: 30).

This article aims to present a practical discussion on the benefits and complications I have encountered as an insider church-historical researcher in the Laestadian Word of Peace branch (WoP). Starting with a brief presentation of WoP and my relationship to it, I will continue reflecting on my insiderness during the stages of the research process. The article ends with a concluding discussion.

\section{Inside the Word of Peace branch}

WoP is a Laestadian sub-branch which in the year 1934 emanated from the Conservative Laestadians, the largest Laestadian group since the schism which occurred at the end of the nineteenth and beginning of the twentieth century. After this emergence from Conservative Laestadianism, the majority of the Swedish-speaking Conservative Laestadians in Ostrobothnia affiliated with the WoP (Wentin 1986: 69-76; Talonen 2001: 13-16). Other adherents of WoP were found among the Finnish-speaking Laestadians in the north of Finland, and Laestadians in the north of Sweden, Norway, and North America (Snellman 2011: 49-50). ${ }^{2}$

2 The five 'members' of the Word of Peace branch are the Laestadians in the prayer house congregations in the Laestadian Federation of the Peace Associations (Laestadianernas Fridsföreningars Förbund, abbreviated LFF), the so-called LFF Laestadianism, the Mission Association of the Word of Peace (Lähetysyhdistys Rauhan Sana ry) in the northern parts of Finland, the Swedish Laestadians in the valley of the Tornio River, the so-called East-Laestadianism or the Laestadianism of the valley of the Tornio River (Tornedalslaestadianismen), the Norwegian Laestadians in the area of Alta, the so-called Alta Laestadianism, and, finally, the Apostolic Lutheran Church of America (ALC). 
The WoP adherents in Ostrobothnia are members of the prayer house congregations, which in 1968 constituted the Laestadian Federation of the Peace Associations (Laestadianernas Fridsföreningars Förbund, abbreviated LFF). ${ }^{3}$

LFF is the publisher of the Sions Missionstidning (Zion's mission magazine, abbreviated SMT), a monthly bulletin which serves as a voice/spokesman for the Swedish- (and Norwegian-) speaking WoP adherents, thus emphasizing the cultural identity of the group. ${ }^{4}$ SMT has been the primary source in several studies I have conducted. Each prayer house association plans their activities sovereignly: religious meetings, Sunday school for children, and handiwork meetings for women. Recently, there have been youth groups, Bible studies, and, besides, activities organized by LFF, such as men's nights, women's nights, youth nights, and children's camps during the summer.

WoP has grown, as have other Laestadian branches since the final decades of the nineteenth century, as a consequence of religious education within the Laestadian homes. Hence, the Laestadian heritage has been transmitted to the younger generations through the upbringing of the children (Raittila 2005: 16). WoP is generally considered a moderate conservative Laestadian sub-branch, compared to Conservative Laestadianism. There is a diversity within WoP, in the form of various

3 The LFF consists of nine prayer house congregations in Finland, of which eight are situated in Ostrobothnia and one in Helsinki. The LFF Laestadians are approximately 6,400 people, the children included, based on data from the membership registers 2019.

4 For more information about SMT see Snellman 2017: 13-15; Enkvist et al. 2018: $12-13,65$. religious-theological accents, which makes the WoP more pluralistic than Conservative Laestadianism (Talonen 2019: 46). The formal connection between the largest Laestadian branches, such as the Conservative Laestadians, the Firstborn Laestadians, and WoP has namely been non-existent (Snellman 2011: 51-5). Hence, a WoP adherent is formally a (spiritual) outsider when entering into some of the other mentioned branches. However, due to characteristic features of the Laestadian tradition, communication between the members of various Laestadian groups has occurred (Raittila 2005: 15).

I am, according to Stephen E. Gregg and George D. Chryssides (2019b: 23), what is called a 'birth-insider', being born into a Laestadian family and enculturated into the WoP culture. I grew up as the next oldest in a family of eleven siblings. I consider my childhood family to be semi-conservative, which means partially comprising the set of norms of Laestadianism. Some of my friends had to observe, for instance, stricter rules when it came to clothing. I attended Sunday school in the local prayer house. I was twelve years old when I started to play the organ in the prayer house meetings and accompanied the singing until I moved away from the village. My father became a lay preacher when I was an adolescent. As an adult, a married woman, and a mother, I considered my family to be a Laestadian family. I have been involved in various projects within the prayer house congregation and the LFF. Part of the time for my doctoral studies, I was a member of the board in the prayer house in Pietarsaari.

\section{Reflections on the pros and cons of insider research}

In this section, I will describe the research process, beginning with the fieldwork mainly connected to my dissertation, and, 
besides, a few later studies. I will continue by scrutinizing interpretation of data, gained both from fieldwork and written sources.

For the main part, in the church-historical research into the Laestadian movement in the twentieth century, the women have been invisible. An exception is Den himmelska Föräldern. Ett studium av kvinnans betydelse i och för Lars Levi Laestadius' teologi och förkunnelse by Kristina Nilsson (1988). Nilsson, who used mainly written sources which had been used by many researchers before her, featured the most important women in Laestadius's life. Thus, there was a need for a change in focus in order to visualize Laestadian women's lives. As the focus on historical research into Laestadianism shifted to the fields of the sociology of religion, social science, and politics, the focus also shifted from the institutional Laestadianism to everyday lives within Laestadianism (see Hintsala 2017: 31-2). This change of focus has served to reveal more about the Laestadian women (and men). There have been methodological changes, too. MeriAnne Hintsala (2017) used ethnography and content analysis in her research about how Laestadian teaching is embodied in the adherents' everyday lives, in using discussions on internet forums as sources. Sandra Wallenius-Korkalo (2018) has studied Laestadianism in popular culture in the field of feminist political studies, religious studies, and cultural studies.

The studies mentioned above, which are concerned with Conservative Laestadianism, are good examples of new methodological approaches. When I started my church-historical research into women, the interest in women in church history had been growing, and new methods had been suggested (see Franzen 1990). For the topic

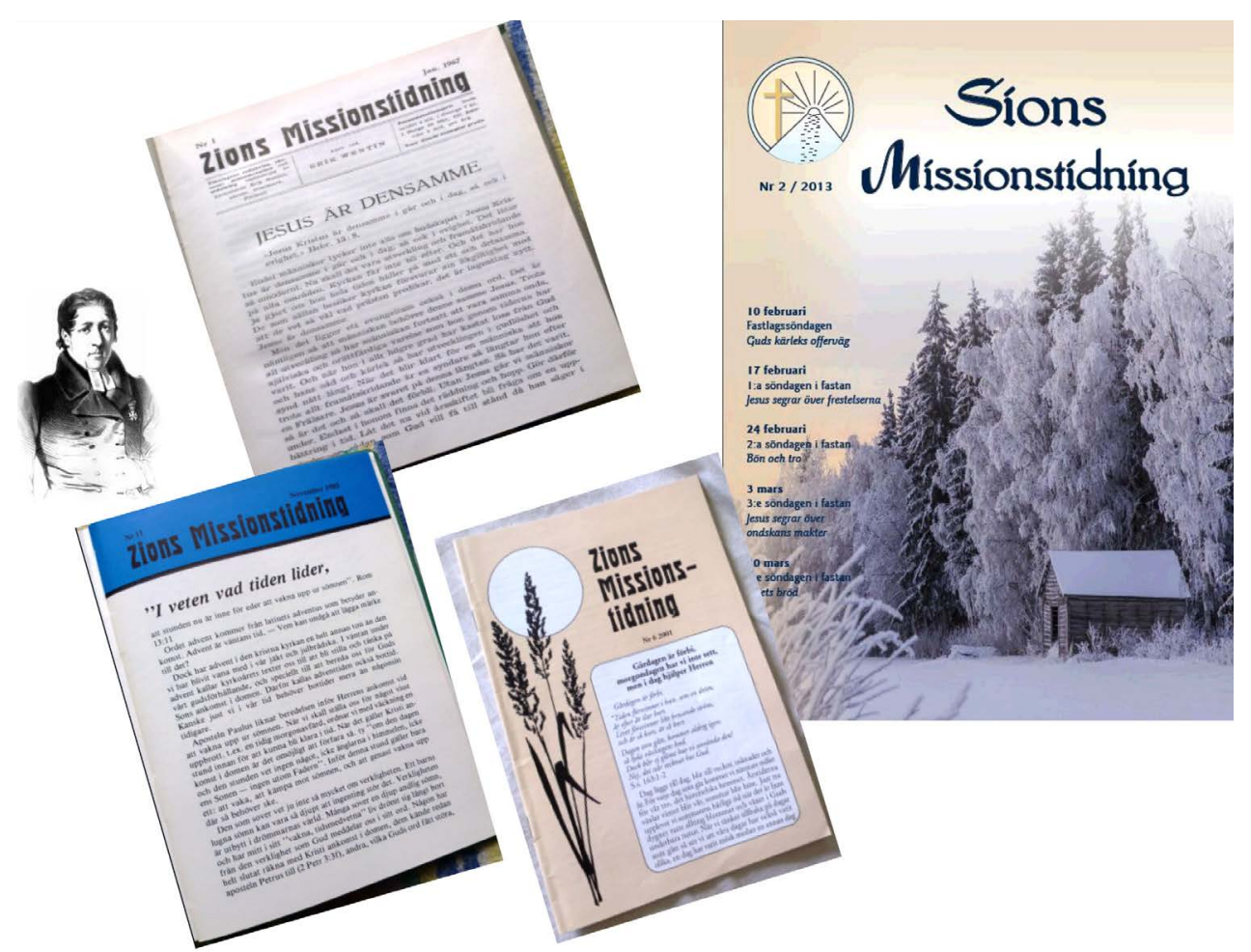

The most common portrait of Lars Levi Laestadius (Wikipedia) and the cover pages of Sions Missionstidning (Zion's mission magazine) from the 1960s and forward. 
chosen, I knew that written sources were less likely to be found. Inspired by Katarina Lewis's ethnographical research on the Schartauan women (1997) in Sweden, I chose the ethnographic approach, including memory as a source of knowledge, to uncover the daily activities of the women. Hence, interviews constituted the most important sources of my research, together with written sources, for example, SMT.

In selecting a good representation of interviewees, I utilised my prior knowledge about the historical development of the WoP community. The 'conservatives' and 'liberals' within families and family networks were, to some extent, known. However, I wanted to present neither a 'happy story' nor a 'sad story'; rather the complex stories of living within WoP. By using various tools, I tried to avoid the risk of bias in the selection of participants (see Chavez 2008: 479).

\section{Spiritual identity reinforces access and trust}

It is generally assumed that a common culture between the researcher and the studied group can provide a fertile ground for gaining access and nurturing rapport (Lee 2000). This 'expediency of access' (Chavez 2008: 482) involves acceptance by the members of the studied group (Greene 2014: 5). To be regarded as a WoP adherent, I had to relate to the WoP community spiritually. One criterion warranting the designation of insider was attending the meetings held in the WoP prayer house on Sundays, and the larger conventions throughout the year (Snellman 2011: 2468). Showing an interest in 'listening to the word of God' was likely to confirm my spiritual identity. However, the WoP identity also includes - like other religious identities - a social identity (pp. 257-8). Depending on the relational, political, or environmental context, specific identification can inter- sect with the religious identity in a variety of ways (Ganiel and Mitchell 2006: 18). Some aspects of the researcher's social identity may benefit, while others may complicate the process (Chavez 2008: 491). My gender, combined with the fact that I was a student of theology, constituted, in my case, possible complications to my insider status. Though labelling myself an insider, I was not sure whether the WoP community would actually consider me to be one. I was the first WoP woman in the area to be conducting doctoral research in theology, which would possibly be an obstacle for being perceived as an insider researcher. Would I be trustworthy, or was I too peculiar? Would the WoP community doubt my intentions? My theological studies would possibly be regarded as a means of becoming a woman priest. Since the WoP community officially rejects the idea of women priests (see Snellman 2011: 90, 120), my theological studies could easily position me as an outsider researcher. Another possible obstacle pertained to the prayer house activities I was involved in. As a figurehead of the children's camps and, later on, women's nights, I was fully aware of the controversies which had arisen around these, which were, for the WoP community, new activities (see Enkvist et al. 2018: 66).

In the end, I do not know to what degree the issues mentioned above influenced the fieldwork. Maybe they were part of the reason why some of the potential interviewees I contacted declined to participate in the study without giving further explanation (Snellman 2011: 32). The major proportion agreed to participate; altogether 19 WoP women and a few men. The fact that the informants knew my parents when I further introduced myself, seemed to facilitate the connections, similarly as it did for Christina Chavez when studying her Mexican family (Chavez 2008: 481-2). 
Because of my doctoral thesis, and the acquisition of a researcher's identity and role, I have felt confident about proceeding using interviews as sources. In one research project within the field of social sciences I needed access to an enterprise, while the aim of the research was philanthropic activities in the business (Snellman 2019: 161-97). The sources of the research were mainly interviews and historical writing of the enterprise. This time I was not only a part of the same WoP community as the people I was going to interview, but also related through marriage. Furthermore, I had been employed by the company earlier and been involved in different projects after employment. Due to my bonds to this object, I referred to an autoethnographic method; the narrative autoethnography (Adams et al. 2015; Ellis et al. 2011). This research methodology embeds critical reflections in the process and is proposed as a particular qualitative method suitable for insider research (Chavez 2008: 490; Greene 2014: 10).

In one study in progress, I co-researched together with a non-Laestadian colleague. The project is a part of research into the European Bible Belts, and the aim of our study is the WoP view on education. For the interviews, I put a note on my Facebook page, where I asked for WoP volunteer interviewees. To my colleague's and my own great satisfaction, we received enough responses from people who wanted to share their experiences with us. My colleague does not have a Facebook account, so we will never know the possible influence of the fact that I, a WoP adherent, was the one asking for participants. My non-Laestadian colleague interviewed some of the participants nevertheless, and there did not seem to be any difference between mine and his experiences in doing the fieldwork.

Hence, trust, according to my experi- ence, has brought great benefits. It has been manifested especially in facilitating access to participants of my studies; but also when I have asked for access to archives and permission to read protocols. Having said this, though, I have not gained access to every subgroup within WoP. A smaller group, who attend both some of the traditional prayer house services, arrange, besides, their own independent gatherings. The members of this group have separated themselves from the LFF prayer house association, supposedly as a consequence of the changes within the LFF over the past ten years. A lack of trust may explain the denial of access. From the vantage point of this group, I am regarded as a spiritual outsider.

\section{Interviewing 'sisters and brothers in faith'}

Even though I had access to the field, I felt that access also needed to be negotiated for every interviewee (see Chavez 2008: $488,490)$. In this way I found that trust needed to be earned again and again in different situations (Iancu and Kovacs 2015: 178). Despite being a spiritual insider, my combined status as a WoP woman and a researcher made me at the same time an outsider. As a historically skeptical attitude towards 'worldly' knowledge has, to some degree, been embraced within the WoP, my academic research would presumably be dubious from this perspective (Snellman 2011: 86-8). The spiritual reciprocity seemed to be the dominant factor, though. I assumed that faith among the WoP adherents would be a highly personal issue and that they might be unwilling to articulate it. As Katarina Lewis had found concerning the Shartauan women, I imagined that similarly amongst the WoP women, the standpoint would be found that 'one shall not talk so much' (Lewis 1997: 122). This reluctant attitude I also found amongst 


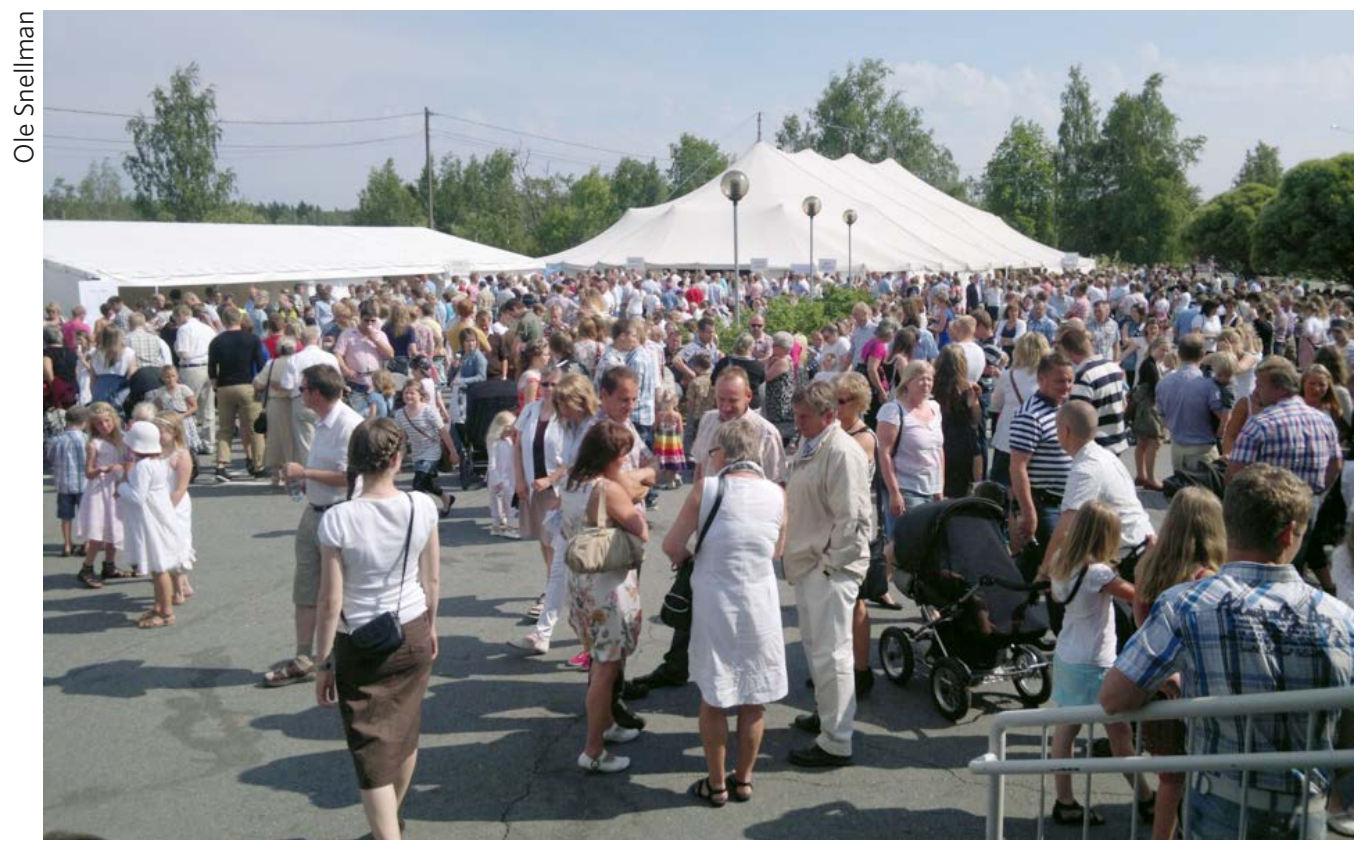

Spring service in Bosund, Larsmo 2011.

some of the interviewees (Snellman 2011: 188-91). However, it is hard to say if this was a cultural, generational, or a personal issue. It is also difficult to say to what extent my insiderness promoted or prevented the women's speech. It has been suggested that participants are more willing to disclose their views to an insider as opposed to an outsider researcher. However, it is also claimed that the participants may be unwilling to share their inner thoughts with an insider, who presents the possibility of judging them negatively (see Tinker and Armstrong 2008: 56; Finefter-Rosenbluh 2017: 2; Greene 2014: 3-4). Many interviewees, though, seemed more than willing to share their personal stories with somebody intent on listening. The purpose of the interview seemed to be a minor issue. I - for my part - felt compelled to move back and forth between the insider and the outsider position, not only during the fieldwork but also in the interpretation and writing process.

One of the advantages of being an insider researcher is a greater understanding of the studied culture (see, e.g., Steinlien 1990). The insider possesses a more profound knowledge of the history of the culture and practical ways of living inside the culture (Chavez 2008: 481). Although, as Mark Q. Gardiner and Steven Engler (2012: 241) have claimed, knowing a religious language is not a prerequisite for access to a specific piece of knowledge (monopolistic), it does, in my experience, notably promote access and trust. So did my internalized use of the 'language of Canaan'5, of which the greeting 'God's peace', for example, is most important (Snellman 2011: 248). Thus, I initially greeted the informants in the letters I sent, and on the phone, with 'God's peace', which confirmed my insiderness (pp. 254-6). The 'language of Canaan' consists, besides, of biblical phrases. It is used

5 A biblically influenced language containing pious expressions (see Snellman 2018: 16). 
in the sermons, but to a certain extent, also in everyday life. The 'language of Canaan' reinforces group identity (p. 250) and functions presumably within WoP in the same way as it does within the Conservative Laestadianism; it represents safety and continuity (Linjama 2013: 42-50). ${ }^{6}$

The exact meaning of the language of Canaan', though, is occasionally unspecified. This blurriness implies a possible home-blindness by the insider researcher (see Iancu and Kovacs 2015: 160). For instance, the interviewees used the term 'Christian' in different contexts. To whom was the informant referring when she or he talked about 'Christians', or even 'God's children'? Were they only the WoP members, or possible members of a non-Laestadian congregation? My knowledge of the WoP culture, the WoP adherents, and the history of WoP in the area enabled follow-up questions. Still, I think an outsider would have been equally able to elaborate on the topic (see Tinker and Armstrong 2008: 56).

However, any (outsider) researcher can interpret the 'language of Canaan', which includes expressions originating from early Laestadianism. For example, Pekka Raittila (1976: 248-53) and Lilly-Anne Østtveit Elgvin (2010) have presented useful knowledge about language-use within the early, undivided Laestadian revival movement, and that of Laestadius himself. Still, there are variations; local dialects of the language of Canaan', in SMT, the written source I have used in a couple of studies (Snellman 2017,2018 ). It seems to me that an outsider

6 Linjama has described the use of the 'language of Canaan' in the Conservative Laestadianism, but this cultural phenomenon is a part of identity construction in the WoP as well (Snellman 2011: 248-56). researcher would need assistance to distinguish, for example, the various expressions for the confession of sin and receipt of absolution, used in SMT. The confession of sin publicly or privately to another believer expressed as 'Open your mouth and ask for forgiveness in Zion', is quite easy to grasp. However, the following necessary absolution expressed as 'while there is an open well for all sin and uncleanness in Zion', might need a more profound understanding to grasp the meaning of. Confession of sin and absolution can be expressed in one phrase, for example, 'to pour water out of the well of health', or, 'to cleanse one's robe in the blood of the offered lamb' (Snellman 2018: 16, 18). The expressions mentioned here need, at least, a basic knowledge of the religious language, in this case, the 'language of Canaan'. Even for me, an insider researcher, the meaning of some expressions was not accessible.

The major portion of the interviews was conducted in a spirit of closeness due to our mutual background. Still, I experienced the negotiation of my subjectobject position, especially in interviewing the mothers. On the one hand, being a Laestadian mother myself facilitated topics affiliated to motherhood, such as giving birth to many children - even though my family is relatively small compared to the customary large Laestadian families. On the other hand, the topic had been a sensitive issue for me, and I knew it was somewhat controversial to discuss. There was a risk of discussing the use of - or the lack of the use of - contraceptives as an issue between 'sisters in faith. These discussions were moments when I had to maintain an appropriate, scientific attitude to avoid the risk of projecting myself on the interviewee, as other insider researchers have experienced (Chavez 2008: 489; FinefterRosenbluh 2017: 2). 
The closeness was challenging at times due to my combined roles. I was a researcher, 'a sister in faith', and, besides, practising as a lay counsellor within the WoP community. Thus some interviews occasionally turned into confessions of sin (by the informants) and absolution (by $\mathrm{me})$. This insertion of a counselling session, - to me not an unfamiliar situation at all alerted me to the need to separate my roles. In alternating between my two roles, there was a need to know when one role ended and the other began. In transcribing the interviews, these confessional situations were left unwritten.

Insiderness and outsiderness are flexible in regard to the possibility of their various degrees (Gardiner and Engler 2012: 242), as all cultures contain internal variations. In religious groups, there are, for example, liberals and conservatives. My (spiritual) insiderness was questioned when I interviewed an elderly woman, and I, interestingly enough, found myself being the object of rebuke by the interviewee. ${ }^{7}$ This incident happened when I asked questions about some doctrinal issues, which, according to the interviewee, should be evident to me as a believer. When the woman asked for my opinion about a specific issue, and I disagreed with her, I was rebuked (Interview with Linnea 2008: 11). Thus, my (spiritual) insiderness shifted during the interaction with this informant. I was not a complete insider, as I was considered by her to be too liberal. Hence, one's position shifts during the research; one's status as an insider or an outsider rarely is straightforward (Ganiel and Mitchell 2006: 15; Chavez 2008: 478).

7 I did not encounter hour-long 'fire-andbrimstone' sermons, though, which Øystein Stenlien did in his fieldwork (Steinlien 1990: 43).

\section{Both a subject and an object in analysing} and writing

In the insider-outsider debate, Katie Aston (2012) has maintained the need to take on a third position; the academic role, in the interpretation and writing, while the presentation of the research results takes place in the secular, empirical tradition. Despite the status of either an insider or an outsider researcher, the personal experiences, thoughts, needs, and ethical deliberations affect not only the data collection but interpretation and application of the findings, as well. There is a need for reflexivity, internal dialogue, and critical self-evaluation, about one's positionality (Finefter-Rosenbluh 2017: 2). The risk that the analysis of data is a projection of my opinions, rather than an interpretation of the actual phenomenon arising from the interviews, has continuously occupied my mind. Still, I have decided not to submit my analysis to the interviewees to receive their opinion of it as Margaret M. Poloma (2003: 254) did to those involved in her ethnographical research in the Toronto Blessing. Instead, I have adhered to chosen theoretical frames in the process of analysis of the data.

The weaknesses inherent in being enculturated into the studied culture include risks of home-blindness and subjectivity. I have acknowledged these risks during the analysis stage and also in applying the findings. The challenge was - and still is - to maintain a sense of critical distance from the topic under investigation. I am fully aware that emotions need to be taken into account, both the emotions of my own and those of the interviewees, and the impact they may have in the analysis.

As a way of taking responsibility for my situatedness within my research, and the effect it may have on the data interpretation, I have used mixed methods, multiple sources, and various theoretical 
frameworks. Discussions with co-researchers and the interrogation of peer reviewers through the publication process have been other ways of ensuring the credibility of the analysis.

Looking at my own culture through the lens of the outside world has promoted problematic common expressions and particular phenomena. During the period of my research on the WoP women, the WoP community was occasionally discussed in the media. Some blog-postings and the often anonymous postings in the local newspaper were useful tools for learning about the opinion of the WoP in society at large and thus problematic self-evidences inside the movement (Snellman 2011: 60-3).

One weakness of being an insider researcher, connected to the risk of hurting people, is that one might avoid stressing negative phenomena, as Pihla Vuorinen (2002) found when using family narratives in her research. Sensitive issues and unsolved dilemmas in WoP include, for example, the congregational role of women. The discussion about female priests had been only partially conducted when I carried out the interviews for my dissertation. Notwithstanding the unanimous standpoint that women should not be priests, a thorough discussion about possible other congregational roles of women was lacking (Snellman 2011: 274-5). The question about female Sunday school teachers was connected to this issue. Upon researching the WoP Sunday school in Pietarsaari (Snellman 2013: 339-54), where the sparse, early protocols indicated that there had been female Sunday school teachers before the mid-nineteenth century, I had access to contradictory sources of memory knowledge, as well. Still, I adhered to the written sources. The issue of female Sunday school teachers was sensitive. The Sunday school in my prayer house had, by the time of my research, been reorganized a few years earlier, and female Sunday school teachers reappeared after a break of over 60 years. Some of the prayer house congregation did not approve of the change.

In the midst of my research on WoP women, the prayer house in Pietarsaari was shaken by a tragedy. It was revealed that a respected, and by that time deceased, lay preacher had been a paedophile (see, e.g., Wolf-Knuts 2016, 2017). ${ }^{8}$ I, for instance, as both a researcher and a member of the prayer house board, would not have been able to research the topic then. Firstly, I was too involved in the case. Secondly, researching at that time would have further hurt already hurting people. Thirdly, my research would not have been unbiased. Fourthly, I would not have wanted to present negative things about my group to the public.

The interpretation and writing seem to me to be like an intertwined process. In the analysis of the data, I have analysed my own culture, as well. I am both the author and object of my texts. I agree with Christina Chavez (2008: 474-81) that both insider and outsider researchers share similar methodological issues, and both are thus, more or less, co-participants in the research.

\section{Conclusion}

The purpose of this paper has been to reflect on the experiences of being an insider researching the WoP community. I began by briefly introducing the insider-outsider

8 The research into the chain of events connected to the so-called paedophile scandal is sparse. Except for the mentioned studies, M.Theol. Lennart Ventin's master's thesis deals with collective shame and self-comprehension in the prayer house congregation (Ventin 2014). 
debate and continued with a scrutiny of my research. As an insider researcher, I have used mainly qualitative methods, and, to some extent, ethnographical tools. I have examined the content of the belief-system and practice within WoP. Besides, I have scrutinized WoP adherents' motivations in beliefs and practice.

In reflecting on my status as an insider, I have found, like many others before me, that there are benefits as well as challenges involved in being part of the studied culture. Many of the benefits of insiderness are also challenges to outsiderness and vice versa. Two main issues seem to connect the insider and outsider researcher; namely trust and reflexivity.

Even though the trust was established through my spiritual insiderness, the identification that seemed to outweigh other social identities, long-term fieldwork can move an outsider closer to the position of the insider. The degree of outsiderness thus shifts during research in similar ways that insiderness does (Iancu and Kovacs 2015: 179; Gardiner and Engler 2012: 242). I think any researcher can earn trust, despite the lack of spiritual insiderness in WoP, while trust may help intersecting imagined social boundaries (see Ganiel and Mitchell 2006: 16).

Trust has continually occupied my mind through the research. Access to a particular element of understanding of the interviewees' experience does not automatically grant me the authority to interpret those experiences. Trustworthiness includes reflexivity, which pays attention to how experience, knowledge, and social positions might impact the research process' (Finafter-Rosenbluh 2017: 2). There is a need for a systematic approach to being on the inside, and Christina Chavez suggests that the insider researcher gets 'into their own heads first before getting into those of participants' (2008: 491). Reflexivity, in my case, has involved acknowledging the difference between my pre-assumptions of how things are, and how things seem to be - and how I wish things to be. Of course, reflexivity in all research is crucial, while both insider and outsider researchers will form a relationship with the studied culture (Chiener 2002: 456-86).

Reflexivity means furthermore, to me, acknowledging the changes in my relationship to the practices and beliefs of WoP during my research. I agree with Deidre Meintel and Géraldine Mossière (2012: $145)$, in their study of migrants in religious groups in Quebec, that outsiders may start to question their religiosity or their lack thereof, while insiders will adopt critical perspectives on their former beliefs. I am by nature a persistent researcher who never leaves the field, and besides that I am involved in various projects in the local prayer house and LFF. This ongoing interaction influences me; as Kim Knott (2014: 105) has maintained, studying religion 'will likely challenge and change the religion in very small or in very big ways'. I believe that my research has an impact on the WoP environment too. One possible contribution is that my thesis has introduced a nonsacral language to describe the meanings of the symbols and belief systems of WoP. The introduction of this new language may have promoted discourse and critical reflections within the WoP community.

Finally, as far as the construction of knowledge in the insider-outsider debate is concerned, I would agree with Sharan Merriam and Maxanah Muhamad (2000) that 'what an insider understands will be different from, but as valid as what an outsider understands'. Instead of trying to erase the boundaries between insiderness and outsiderness I embrace the complexity of the definitions. Insiderness and 
outsiderness do not have to compete; rather they may complement each other. I think that Professor Ruth Franzén's statement, when discussing women's studies, is applicable in the discussion about insiderness and outsiderness:

Research will be successful when the researchers, according to their background and personal reference frames, represent as broad a width as possible. Only then can a research community correct itself and explore even the blind spots which otherwise distort the research results. (Franzén 1990: 122-3, my translation) $)^{9}$

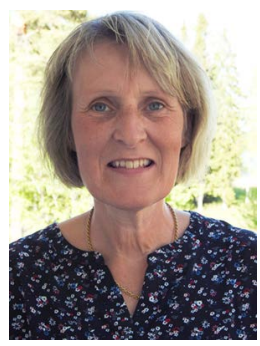

Gerd Snellman, ThD, is a freelance researcher affiliated to Church History Studies at Åbo Akademi University. Her main research interest is the Laestadian movement in the Swedish-speaking parts of Finland. In the frame of the study of Laestadianism, she has pertained to women's studies, cultural memory studies, the history use within the Laestadianism, and social science. Gerd Snellman is a member of the Nordic revival research network Nordveck.

\section{List of references}

\section{Archive material}

Interview with Linnea, 2008. Private archive

\section{Bibliography}

Adams, Tony E., Stacy Holman Jones, and Carolyn Ellis, 2015. Autoethnography: Understanding Qualitative Research (Oxford University Press)

9 'All forskning vinner på att forskarna till sin bakgrund och sina personliga referensramar representerar en så stor bredd som möjligt. Endast på det sättet kan ett forskarsamfund effektivt korrigera sig självt och utforska också de blinda fläckar som annars förvränger forskningsresultaten.'
Aston, Katie, 2012. 'Insider and outsider: an anthropological perspective', in The Religious Studies Project, 24.2.2012, $<$ https://www.religiousstudiesproject. com/2012/02/24/katie-aston-insider-andoutsider-an-anthropological-perspective/> (accessed 25.8.2019)

Chavez, Christina, 2008. 'Conceptualizing from the inside: advantages, complications, and demands on insider positionality', in The Qualitative Report, 13(3), pp. 474-94

Chiener, Chou, 2002. 'Experience and fieldwork: a native researcher's view', in Ethnomusicology, 46(3), pp. 456-86, <https:// www.jstor.org/stable/pdf/ 852719 . pdf?seq $=7$ \#metadata_info_tab_contents $>$ (accessed 27.2.2020)

Duffy, Joshua, 2014. 'Knowing religion: the insider/outsider debate', <https://www.academia.edu/16657431/Knowing_Religion_ The_Insider_Outsider_Debate> (accessed 25.8.2019)

Ellis, Carolyn, Tony E. Adams, and Arthur P. Bochner, 2011. 'Autoethnography: an overview', in Forum Qualitative Sozialforschung / Forum Qualitative Social Research, 12(1), art. 10, <http://www.qualitative-research. net/index.php/fqs/article/view/1589/3096> (accessed 27.2.2020)

Enkvist, Stig-Erik, Roger Pettersson, and Gerd Snellman, 2018. Ett halvt sekel med LFF. Laestadianernas Fridsföreningars Förbund rf 1968-2018 (Jakobstad, Laestadianernas Fridsföreningars Förbund rf)

Finefter-Rosenbluh, Ilana, 2017. 'Incorporating perspective taking in reflexivity: a method to enhance insider qualitative research processes, in International Journal of Qualitative Methods, 16,pp. 1-11<https://journals.sagepub.com/doi/10.1177/1609406917703539> (accessed 27.2.2020)

Franzen, Ruth, 1990. 'Kvinnoperspektiv på kyrkohistorisk forskning', in Kirkko ja politiikka. Juhlakirja professori Eino Murtorinteen täyttäessä 60 vuotta 25.11.1990, Suomen kirkkohistoriallisen seuran toimituksia, 153 (Helsinki, Suomen kirkkohistoriallinen seura), pp. 113-29

Ganiel, Gladys, and Claire Mitchell, 2006. 'Turning the categories inside-out: complex identifications and multiple interactions in religious ethnography', in Sociology of Religion, $67(1)$, pp. 3-21 
Gardiner, Mark Q., and Steven Engler, 2012. 'Semantic holism and the insider-outsider problem', in Religious Studies, 48, pp. 239-55, doi: <https://doi.org/10.1017/ So034412511000205> (accessed 25.8.2019)

Greene, Melanie J., 2014. 'On the inside looking in: methodological insights and challenges in conducting qualitative insider research', in The Qualitative Report, 19(29), pp. 1-13, $<$ https://www.academia.edu/7292274/ On_the_Inside_Looking_In_Methodological_Insights_and_Challenges_in_Conducting_Qualitative_Insider_Research._The_ Qualitative_Report_19_29_> (accessed 27.2.2020)

Gregg, Stephen E., and George D. Chryssides, 2019a. 'Preface', in The Insider/Outsider Debate: New Perspectives in the Study of Religion, eds. George D. Chryssides and Stephen E. Gregg (Sheffield, Equinox Publishing Ltd.)

- _ 2019b. 'Relational religious lives: beyond insider/outsider binaries in the study of religion, in The Insider/Outsider Debate: New Perspectives in the Study of Religion, eds. George D. Chryssides and Stephen E. Gregg (Sheffield, Equinox Publishing Ltd.), pp. 3-29

Hedges, Paul, and Anna S. King, 2014. 'Is the study of religion religious? How to study religion, and who studies religion', in Controversies in Contemporary Religion: Education, Law, Politics, Society, and Spirituality, vol. 1: Theoretical and Academic Debates, ed. Paul Hedges (Santa Barbara CA, Praeger), pp. 31-56

Hintsala, Meri-Anna, 2017. Taivasta varten ja luotu. Usko ja ruumis vanhoillislestadiolaisuutta koskevissa verkkokeskusteluissa, ThD dissertation (Faculty of Theology, University of Helsinki), <http://urn.fi/ URN:ISBN:978-951-51-3596-4>

Iancu, Laura, and Magdolna Kovacs, 2015. 'Considering insiders, outsiders and in-between: reflections on fieldwork in Magyarfalu', in Culture, Language and Globalization among the Moldavian Csángós Today, eds. Magdolna Kovacs, Petteri Laihonen and Hanna Snellman, Uralica Helsingiensia, 8 (Helsinki, The Finno-Ugrian Society), pp. 159-81

Knott, Kim, 2008. 'Inside, outside and the space in-between: territories and boundaries in the study of religion', in Temenos, 44(1), pp. 41-66

- - 2014. 'The skills of reflexivity and some key categories: the terms of our time travel', in Comparing Religions: Coming to Terms, eds. Jeffrey J. Kripal, Ata Anzali, Andrea R. Jain and Erin Prophet (Malden, John Wiley \& Sons Ltd), pp. 77-108

Lee, Ming-yeh, 2000. 'Interviewing within your own culture away from home: its effect on insider/outsider status', in 'Power and positionality: negotiating insider/outsider status in multicultural and cross-cultural research' by Sharan Merriam, Gabo Ntseane, MingYeh Lee, Youngwha Kee, Juanita Johnson-Bailey, and Mazanah Muhamad, Adult Education Research Conference, <https:// newprairiepress.org/aerc/200o/symposia/3/> (accessed 17.2.2020)

Lewis, Katarina, 1997. Schartauansk kvinnofromhet $i$ tjugonde seklet. En religionsetnologisk studie, $\mathrm{PhD}$ dissertation (Uppsala University)

Linjama, Topi, 2013. "Emmekö ole aivan kuin ajattelemassa", in Lestadiolaisuus tienhaarassa, eds. Matti Myllykoski and Mikko Ketola (Helsinki, Vartija and authors), pp. 42-50

MacIntyre, Alasdair, 1999. 'Is understanding religion compatible with believing?', in The Insider/Outsider Problem in the Study of Religion: A Reader, ed. Russell T. McCutcheon (London, Continuum), pp. 37-49

McCutcheon, Russell T. (ed.), 1999. The Insider/ Outsider Problem in the Study of Religion: A Reader (London, Continuum)

Meintel, Deirdre, and Géraldine Mossière, 2012. 'Going through the back door: studying ethnicity via religion', in Where is the Field? The Experience of Migration Viewed through the Prism of Ethnographic Fieldwork, eds. Laura Hirvi and Hanna Snellman, Studia Fennica Ethnologica, 14 (Helsinki, SKS), pp. 145-6, doi: <http://dx.doi.org/10.21435/ sfe.14>

Merriam, Sharan, and Mazanah Muhamad, 2000. 'On dealing with insider/outsider issues in a cross-cultural team', in Power and positionality: negotiating insider/outsider status in multicultural and cross-cultural research, by Sharan Merriam, Gabo Ntseane, Ming-Yeh Lee, Youngwha Kee, Juanita 
Johnson-Bailey, and Mazanah Muhamad, Adult Education Research Conference, $<$ https://newprairiepress.org/aerc/200o/ symposia/3/> (accessed 17.1.2020)

Narayan, Kirin, 1993. 'How "native" is a native anthropologist?', in American Anthropologist, New Series, 95(3), pp. 671-86, <https:// www.jstor.org/stable/679656? read-now $=1 \&$ refreqid=excelsior\% 3 A257ec16064fe89ca6 8d8144e752735ec\&seq=1\#page_scan_tab_ contents $>$ (accessed 27.2.2020)

Nilsson, Kristina, 1988. Den himmelska Föräldern. Ett studium av kvinnans betydelse $i$ och för Lars Levi Laestadius' teologi och förkunnelse, ThD dissertation (Uppsala University)

Østtveit Elgvin, Lilly-Anne, 2010. Lars Levi Laestadius spiritualitet, ThD dissertation (Uppsala University)

Poloma, Margaret M. 2003. Main Street Mystics: The Toronto Blessing \& Reviving Pentecostalism (Walnut Creek, AltaMira Press)

Raittila, Pekka, 1976. Lestadiolaisuus 1860luvulla, ThD dissertation (University of Helsinki)

- - 2005 (1981). 'What is Laestadianism?', in A Godly Heritage: Historical View of the Laestadian Revival and Development of the Apostolic Lutheran Church in America, eds. Aila Foltz and Mirjam Yliniemi (Spruce Grove MN, Editors), pp. 9-16

Snellman, Gerd, 2011. Sions döttrar. De laestadianska kvinnorna som traditionsförmedlare i norra svenska Österbotten åren 19272009, ThD dissertation (Åbo Akademi University)

- - 2013. 'Söndagsskola eller barngudstjänst? Söndagsskolan i Skutnäs bönehus åren 1922-2012', in Historiska perspektiv på kyrka och väckelse. Festskrift till Ingvar Dahlbacka på 6o-årsdagen, eds. Kim Groop and Birgitta Sarelin (Helsinki, Suomen kirkkohistoriallinen seura), pp. 339-54

_- - 2017. 'Att leva rätt och dö saligt. Sions Missionstidnings nekrologer som utformare av kollektivets minne åren 1935-2014', in Väckelser som minnes- och meningsskapande narrativ, eds. Jakob Dahlbacka and Kim Groop (Åbo Akademis förlag), pp. 167-94

- - 2018. 'Maria Ventus. En väckelseröst i Zions Missionstidning åren 1937-1961', in Kvinnor och andlighet $i$ norr, eds. Daniel
Lindmark and Jan Samuelson (Skellefteå, Artos \& Norma), pp. 151-79

——_2019. 'LFF-lestadiolaisyrityksen hyväntekeväisyys Pietarsaaren seudulla', in Politiikka, talous ja työ. Lestadiolaisuus maailmassa, eds. Aini Linjakumpu, Tapio Nykänen, Tiina Harjumaa and Sandra Wallenius-Korkalo (Rovaniemi, Lapland University Press), pp. 161-97

Steinlien, Øystein, 1990. 'The concept of "native" anthropology: fieldwork among Laestadians', in Acta Borealia, 7(1), pp. 40-6, doi: <https:// doi.org/10.1080/08003839008580382>

Sutcliffe, Steven J., 2019. 'The emics and etics of religion: what we know, how we know it and why this matters', in The Insider/Outsider Debate: New Perspectives in the Study of Religion, eds. George D. Chryssides and Stephen E. Gregg (Sheffield, Equinox Publishing Ltd.), pp. 30-52

Talonen, Jouko, 2001. 'Lestadiolaisuuden hajaannukset', in Lestadiolaisuuden monet kasvot, eds. Jouko Talonen and Ilpo Harjutsalo, Iustitia, 14 (Helsinki, Suomen teologinen instituutti), pp. 11-30

- - 2019. 'Laestadiolaisuus, politiikka ja eduskuntavaalit 2015', in Politiikka, talous ja työ. Lestadiolaisuus maailmassa, eds. Aini Linjakumpu, Tapio Nykänen, Tiina Harjumaa and Sandra Wallenius-Korkalo (Rovaniemi, Lapland University Press), pp. 23-58 Tinker, Claire, and Natalie Armstrong, 2008. 'From the outside looking in: how an awareness of difference can benefit the qualitative research process', in The Qualitative Report, (13), pp. 53-60, <https://nsuworks.nova. $\mathrm{edu} / \mathrm{cgi} / \mathrm{viewcontent}$.cgi ?article $=1605 \&$ context $=$ tqr $>($ accessed 28.2.2020)

Ventin, Lennart, 2014. 'Kollektiv skam och självförståelse. En fallstudie av teologi och praxis i Jakobstads Fridsförening r.f.', unpublished master's thesis (Åbo Akademi University)

Vuorinen, Pihla, 2002. 'Doing research among family and friends: problems and advantages', in Lives, Histories and Identities: Studies on Oral History, Life- and Family Stories, eds. Tiiu Jaago, Mare Kõiva and Kairika Kärsna (University of Tartu)

Wallenius-Korkalo, Sandra, 2018. Esitetty lestadiolaisuus. Uskonto, ruumiillisuus ja valta populaarikulttuurissa, $\mathrm{PhD}$ dissertation (Rovaniemi, University of Lapland) 
Wentin, Erik, 1986. Laestadianismen i svenska Österbotten (Vasa, Laestadianernas Fridsföreningars Förbund rf.)

Wiebe, Donald, 1999. 'Does understanding religion require religious understanding?', in The Insider/Outsider Problem in the Study of Religion: A Reader, ed. Russell T. McCutcheon (London, Continuum), pp. 260-73

Wolf-Knuts, Ulrika, 2016. 'Lived forgiveness in a Finland-Swedish Laestadian community', in The Shifting Boundaries of Tolerance: Inclusion, Exclusion, and Religious Communities of Memory, eds. Ingvar Dahlbacka, Kim Groop and Jakob Dahlbacka, Studies on Religion and Memory, 2 (Åbo Akademi University), pp. 110-34

- -2017. 'Den psykologiserande berättaren. Makt och maktutövning som teman i berättande om pedofili', in Väckelser som minnes- och meningsskapande narrativ, eds. Jakob Dahlbacka and Kim Groop (Åbo Akademi University), pp. 261-88 